\title{
Religious Styles Predict Interreligious Prejudice: A Study of German Adolescents with the Religious Schema Scale
}

\author{
Heinz Streib and Constantin Klein \\ Research Center for Biographical Studies in Contemporary Religion \\ Bielefeld University, Germany
}

\begin{abstract}
Based on a sample of 340 German adolescents age 12 to 25 , this article presents an analysis of the effects of religion on two instances of interreligious prejudice: anti-Islamic and anti-Semitic prejudice. Reflecting the emergent interest in implementing a perspective of religious maturity and religious development into research on religion and prejudice, the present study has included the Religious Schema Scale (RSS) which, with its three subscales, Truth of Texts \& Teachings (ttt), Fairness, Tolerance \& Rational Choice (ftr), and Xenosophia/Interreligious Dialog (xenos), differentiates religious styles. Regression analyses indicate the superior explanatory power of the RSS in comparison to other measures of religiosity. The RSS subscale ttt relates to and predicts anti-Islamic and anti-Semitic prejudice, whereas ftr and xenos relate to and predict disagreement with interreligious prejudice. Results of an analysis of variance using high agreement on $\mathrm{ttt}$, $\mathrm{ftr}$, and xenos for group construction indicate a decrease in interreligious prejudice in relation to religious development.
\end{abstract}

\section{PERSPECTIVES FROM THE TRADITION OF RESEARCH ON RELIGION AND PREJUDICE}

For research on religion and prejudice, we can refer to a respectable tradition. Since Allport (1954/1979, 1966; Allport \& Ross, 1967), it is a well-known phenomenon in the field of the psychology of religion that religiosity tends to be associated with prejudice against other people with different ethnic background or religious affiliation. Further, it is well known that Allport also noted the good and bad of religion: Religion can "make" and "unmake" prejudice. It is, however, most important to take into account and reconsider that, according to Allport

Correspondence should be sent to Heinz Streib, Research Center for Biographical Studies in Contemporary Religion, K6-101, Universität Bielefeld, Postfach 100131, D-33501 Bielefeld, Germany. E-mail: Heinz.Streib@uni-bielefeld.de 
(1954/1979, p. 456), the promotion of prejudice is based on religion "of an ethnocentric order" as opposed to religion "of a universalistic order."

An attempt to account for this ambivalence is presented by the distinction between intrinsic and extrinsic religion (Allport \& Ross, 1967) — with the assumption that prejudice is primarily due to the extrinsic or undifferentiated religious orientation (see Batson, Schoenrade, \& Ventis, 1993; Donahue, 1985; Hood, Hill, \& Spilka, 2009; Hunsberger \& Jackson, 2005, for reviews). However, as Hunsberger and Jackson (2005) noted, "the expected relationships have not been broadly substantiated in several decades of research" (p. 816).

Altemeyer and Hunsberger (1992, 2005; Altemeyer, 2003; Hunsberger \& Jackson, 2005; Hunsberger, Owusu, \& Duck, 1999) have focused on another specific set of attitudes related to religiosity, which account for the ambivalent role of religion: religious fundamentalism and right-wing authoritarianism (RWA). Both fundamentalism and RWA are associated with prejudice against various groups including women, African Americans, Jews, and gay people. Altemeyer and Hunsberger $(1992,2005)$ identified at least four mechanisms that facilitate prejudice: moral dualism, the need for social strength of one's own ideology and group, the belief that one's own faith is exclusively true, and a refusal of pluralism. The association between religious fundamentalism, RWA, and interracial prejudice could also be corroborated by using an experimental design (Rowatt \& Franklin, 2004).

The key role of fundamentalism, however, to account for each and every kind of interreligious prejudice has been questioned. For example, in his study of anti-Semitism among Muslim and Christian respondents in America, Baum (2009) found that "while fundamentalism was also linked to greater anti-Semitism among Muslims, this relationship fell just short of statistical significance in the Christian sample" (p. 145). Further, Hall, Matz, and Wood (2010) found that the effect of fundamentalism disappears after controlling for RWA and conclude from a metaanalysis of a series of studies on religion and racial prejudice that it may be RWA rather than religious fundamentalism, which accounts for prejudice. These doubts about fundamentalism as being the key predictor for prejudice may trigger reflection about alternatives to Altemeyer and Hunsberger's (1992) most frequently used Religious Fundamentalism Scale; they do not, however, diminish the necessity to assess the type of ethnocentric religion, which, we still suspect, explains a great deal of the development of prejudice.

\section{RESEARCH ON RELIGION AND PREJUDICE IN GERMANY}

In contrast to North America, there is less research on interreligious prejudice in Germany. One promising project is Heitmeyer's (2002) annual monitoring of group-focused enmity in Germany, which has recently completed its 10th round (Heitmeyer, 2011) and which has been expanded in 2008 to an investigation of group-focused enmity in Europe (Küpper \& Zick, 2010; Zick, Küpper, \& Hövermann, 2011). Also, the factor religiosity has been considered in relation to group-focused enmity in Germany (Küpper, 2010; Küpper \& Zick, 2005) and in Europe (Küpper \& Zick, 2010; Zick, Küpper, \& Hövermann, 2011). Küpper (2010) demonstrated that religiosity in general has a small but significant promoting effect on prejudice. Likewise, from the European study, Zick, Küpper, and Hövermann (2011) reported evidence that "religious respondents are more likely to express prejudices than non-religious respondents" (pp. 148149), and Küpper and Zick (2010, p. 14, cf p. 66) noted that religious people "show more anti- 
Semitism and more negative attitudes towards Muslims." Taking a more differential approach and dividing their sample in 12 groups from "convinced non-religious" over "extrinsic" and "intrinsic religious" to "religious superiority believers," Küpper and Zick (2010) found that "superiority/exclusionary believers are remarkably intolerant towards all target groups" (p. 49). The differentiation of religiousness into such categories, which can help account for superiority and exclusivity of a specific way of being religious, is a promising step; it also reflects variations similar to those described in Allport's work.

\section{PREJUDICE AND RELIGIOUS DEVELOPMENT}

There is another line of research on interreligious prejudice with a focus on religious maturity and thus on religious development. The study by Leak and Finken (2011) reveals a considerable predictive effect of religious fundamentalism and religious openness on prejudice against Muslims. Also, the Faith Development Scale (FDS; Leak, 2008; Leak, Loucks, \& Bowlin, 1999) has been used to assess the effects opposite to religious fundamentalism. Leak and Finken's study demonstrates the efficiency of applying not only a measure of fundamentalism but also a measure of religious maturity for research on religious prejudice. Leak's FDS was also included in a study on prejudice against Muslims in Australia by James, Griffiths, and Pedersen (2011). The authors found that low scorers on the FDS are high on prejudice against Muslims. The FDS emerged as stronger predictor for anti-Islamic prejudice than the Quest Scale, but the Religious Fundamentalism Scale (short version; Altemeyer \& Hunsberger, 2004) exceeded the predictability of the FDS. Overall, using the FDS in research on religion and prejudice is a step forward because it introduces a perspective of religious development in research on prejudice. It falls short, however, when it is used as no more than another one-dimensional measure of (religious) openness. ${ }^{1}$ Eventually, closer attention to the distinct profiling of Fowler's (1981) stages of faith-which have been advanced in a model of religious styles (Streib, 2001; Streib, Hood, \& Klein, 2010)—would have even more effect in predicting and explaining the promotion and prevention of prejudice.

\section{RELIGIOUS SCHEMATA: A PROPOSAL FOR RESEARCH ON RELIGION AND INTERRELIGIOUS PREJUDICE}

The ambivalence of religion to generate hostility, violence, terror, and war, on one hand, and peace, reconciliation, and understanding, on the other, to which we have referred to at the beginning of this introduction, necessitates that a model about the relation of religiosity to interreligious prejudice has to account for the positive and negative effects of religiosity. What version of religion, what kind of religious experiences and beliefs, and what pattern

\footnotetext{
${ }^{1}$ The model of Leak and Finken has combined the FDS, together with a measure for religious quest (a shortened 13-item version of Altemeyer \& Hunsberger's, 1992, Quest scale), into a latent variable called religious openness. Even though the relation of religious development with openness has been evidenced also by other studies (e.g., Streib, Hood, Keller, Csöff, \& Silver, 2009), we may raise the question of whether religious development could not offer more than merely religious openness.
} 
of religious-cognitive structures support, respectively, reduce, interreligious prejudice? The research reported in this text is based on the assumption that, besides particular religious content such as specific images of God, cognitive structural schemata may serve as predispositions for adolescent interreligious prejudice.

An entire spectrum of specific schemata can be identified to be responsible for the genesis of prejudice and violence (cf. Streib, 2008): the schemata of, for example, "an eye for an eye," "scapegoat" (Girard, 1987, 1998), "diabolization," and a violence-related schema such as "exorcism." These schemata may work in association with others such as "dualism," which construes a black and white contradiction between one's own group or nation and the alien, and "de-individualization," which facilitates a disregard for individual uniqueness and therefore facilitates stereotyping others. The operation of such schemata may, in turn, be fueled by literal interpretations of ideological or sacred texts and teachings. This list of schemata with potential to foster interreligious prejudice largely corresponds to Altemeyer and Hunsbergers's (1992, 2005) account.

In the construction of the Religious Schema Scale (RSS; Streib et al., 2010), which is used in this research, the schema of absolutistic, exclusivist, and literal understanding of one's own sacred texts has been operationalized in the subscale Truth of Texts and Teachings (ttt). Sample items are "What the texts and stories of my religion tell me is absolutely true and must not be changed" and "The stories and teachings of my religion give meaning to the experiences of my life and reveal the unchangeable truth about God or the Divine." This scale not only correlates considerably high with the Religious Fundamentalism Scale $(r=.81$ in German and .80 in U.S. samples; see Streib et al., 2009) but also can be expected to also tap into Allport's concept of ethnocentric religion.

The construction of the two other subscales of the RSS is a response to another problem of extant research on religiosity in relation to prejudice: the rather strong focus on the negative, "pathogenic" aspects and limited attention to positive-potentially "salutogenic"-factors. Positive opposites for interreligious prejudice are: the schema of tolerance and fairness, andbeyond tolerance-the schema of appreciation for the other as expressed by the concept of xenosophia, of wisdom in the encounter with the alien (Nakamura, 2000; Waldenfels, 1990, 1997). Thus, to tap "appreciation of the other," a subscale of the RSS was constructed called Xenosophia/Inter-Religious Dialog (xenos). Sample items are "We need to look beyond the denominational and religious differences to find the ultimate reality" and "The truth I see in other world views leads me to reexamine my current views." This subscale clearly reflects Allport's notion of religiousness with a universalistic perspective. A third subscale of the RSS represents another schema that is opposed to interreligious prejudice and exclusivist absoluteness: Fairness, Tolerance and Rational Choice (ftr). Sample items are "It is important to understand others through a sympathetic understanding of their culture and religion" and "We should resolve differences in how people appear to each other through fair and just discussion." The ftr subscale shares with xenos the opposition to ttt but has its own profile of an "objectifying" and supposedly "neutral" approach focusing on justice and fairness.

\section{HYPOTHESES}

It is the general assumption for this research that the schemata that are represented in the RSS, along with other religiousness measures, are related to interreligious prejudice in adolescents. 
More specifically, we hypothesize that (a) the subscale ttt of the RSS together with certain images of God such as God as judge and redeemer predicts interreligious prejudice, and that (b) both subscales of the RSS, ftr and xenos, predict disagreement with interreligious prejudice. These hypotheses were tested among a sample of German adolescents.

\section{METHODS}

\section{Sample}

The sample consisted of 340 adolescents who were 12 to 25 years old $(M$ age $=18.6)$ when they filled out the online-questionnaire in spring and early summer of 2009. Of the participants, 97.6\% report German citizenship; other citizenships are marginal. A majority (92.0\%) belonged to a Christian denomination, $1.8 \%$ were affiliated with another religious organization, $6.2 \%$ were religiously unaffiliated, and a small group of Muslims was excluded from the analyses. ${ }^{2}$ With $60.6 \%$ female participants, gender distribution was not equal, but acceptable. The proportion of adolescents, who still attended school, mostly middle or high school, was 57.4\% (somewhat high for Germany). Of the respondents who did not attend school, $27.5 \%$ were in vocational training, 9.2\% had not started vocational training, 9.2\% completed vocational training, $50.0 \%$ attended college or university, and $3.5 \%$ had a M.A. degree or equivalent.

\section{Instruments}

The online questionnaire contained, besides basic demographic questions for sex, age, ethnic affiliation, and potential immigration background, detailed questions for education and vocational degrees. The religion section of the questionnaire asked for the self-identification of being "religious" and being "spiritual" on 5-point rating scales. The questionnaire also asked about 50 questions on specific religious experiences and beliefs. On the basis of these items, a series of scales were constructed; the following are used in this report: ${ }^{3}$ image of God as helper (five items, Cronbach's $\alpha=.92$, sample item: "God is a friend in heaven"), image of God as judge and redeemer (nine items, Cronbach's $\alpha=.88$, sample items: "The blood of Jesus Christ resolves the relation between me and God," "God is a severe judge who does not allow trespasses"), and mystical experiences (four items, Cronbach's $\alpha=.60$, sample item: "I know experiences that all things in the world are connected in a miraculous and mysterious way").

Another instrument with focus on religion is the RSS (Streib et al., 2010), which was previously introduced and conceptually explained. The RSS consists of three subscales of five items each (for original English items, see Streib et al., 2010, the appendix; for German version, see Streib \& Gennerich, 2011; sample items are quoted previously). Reliabilities of the three subscales in the current sample are Cronbach's $\alpha=.88$ for the subscale ttt, Cronbach's $\alpha=$ .63 for ftr, and Cronbach's $\alpha=.71$ for xenos.

\footnotetext{
${ }^{2}$ A group of Turkish-Islamic respondents $(n=27)$ had been excluded from the original database of 367 total cases because we regarded this group to be too small for comparative analyses and because our analyses included a focus specifically on anti-Islamic prejudice in subjects more in the traditional German mainstream.

${ }^{3}$ Translation of sample items are ours. Unless indicated otherwise, the items and scales are available in German language only and are neither based on an English original nor been translated into English in full length so far.
} 
Interreligious prejudice (i.e., anti-Islamic and anti-Semitic prejudice) was assessed by scales of four items each, from which two in every scale are identical with items in Heitmeyer's (2002, 2007) measures of group-focused enmity (sample item: "Muslims should be denied any immigration to Germany"), the other two are new items (sample item: "Judaism is a distortion of true religion;" "Islam is harmful for world peace"). The scales have reliabilities of Cronbach's $\alpha=.82$ for anti-Islamic prejudice and Cronbach's $\alpha=.81$ for anti-Semitic prejudice.

\section{RESULTS}

Correlations Between Religiosity, Images of God, Religious Schemata, and Interreligious Prejudice

As presented in Table 1, the correlations between self-rated religiosity and the scales for mystical experiences and images of God are all significant and indicate strong coherence. The adolescents appear to associate in particular an image of God as helper with being "religious" $(r=.74, p<.001)$. Furthermore, all of the measures for religiosity, religious experiences, and images of God, especially the image of God as judge and redeemer, have high correlations with the RSS schema ttt—which indicates that, for the adolescents in our sample, being "religious" is closely associated with an absolutist or even fundamentalist style. In contrast, the religious schemata of ftr and xenos are not significantly associated with religiosity, religious experience, and traditional images of God for these adolescents-with one exception: Between the image of God as judge and redeemer and xenos, there was a strong negative correlation $(r=-.42$, $p<.001)$.

TABLE 1

Correlations Between the Scales for Religiosity, Images of God, Religious Schemata and Interreligious Prejudice

\begin{tabular}{|c|c|c|c|c|c|c|c|c|c|}
\hline & $\begin{array}{c}1 \\
\text { rel }\end{array}$ & $\begin{array}{c}2 \\
\text { help }\end{array}$ & $\begin{array}{c}3 \\
\text { myst }\end{array}$ & $\begin{array}{c}4 \\
\text { jure }\end{array}$ & $\begin{array}{c}5 \\
t t t\end{array}$ & $\begin{array}{c}6 \\
f t r\end{array}$ & $\begin{array}{c}7 \\
\text { xenos }\end{array}$ & $\begin{array}{c}8 \\
a s p\end{array}$ & $\begin{array}{c}9 \\
\text { aip }\end{array}$ \\
\hline 1. rel & 1 & $.74 * *$ & $.43 * *$ & $.54 * *$ & $.63 * *$ & .04 & $-.11 *$ & -.04 & .03 \\
\hline 2. help & & 1 & $.43 * *$ & $.66 * *$ & $.75 * *$ & .03 & $-.14 *$ & -.04 & $.14 *$ \\
\hline 3. myst & & & 1 & $.44 * *$ & $.45^{* *}$ & .07 & -.08 & -.05 & $.14 * *$ \\
\hline 4. jure & & & & 1 & $.81 * *$ & $-.14^{*}$ & $-.42 * *$ & $.16 * *$ & $.39 * *$ \\
\hline 5. $\mathrm{ttt}$ & & & & & 1 & -.06 & $-.33 * *$ & $.11 *$ & $.34 * *$ \\
\hline 6. $\mathrm{ftr}$ & & & & & & 1 & $.32 * *$ & $-.47 * *$ & $-.39 * *$ \\
\hline 7. xeno & & & & & & & 1 & $-.16^{* *}$ & $-.41 * *$ \\
\hline 8. asp & & & & & & & & 1 & $.43 * *$ \\
\hline 9. aip & & & & & & & & & 1 \\
\hline
\end{tabular}

Note. $N=339-340$. rel = self-identification as "religious"; help = Image of God: helper; myst = mystical experiences; jure $=$ God image: judge \& redeemer; $\mathrm{ttt}=$ Truth of Texts \& Teachings; $\mathrm{ftr}=$ Fairness, Tolerance $\&$ Rational Choice; $x$ enos $=$ Xenosophia/Interreligious Dialog; asp = Anti-Semitic Prejudice; aip = Anti-Islamic Prejudice.

*Correlation is two-tailed significant on the .05 level. **Correlation is two-tailed significant on the .01 level. 
Correlations between the three religious schemata measured by the RSS are, as in previous research (Streib et al., 2009; Streib et al., 2010), almost zero and nonsignificant between ttt and $\mathrm{ftr}$, negative $(r=-.33, p<.001)$ between $\mathrm{ttt}$ and xenos, and positive between $\mathrm{ftr}$ and xenos $(r=.32, p<.001)$.

As expected, the correlation between anti-Semitic and anti-Islamic prejudice was positive and considerable $(r=.43, p<.001)$ but not high enough to suggest that they are basically the same. Anti-Islamic and anti-Semitic prejudice had no significant correlation with self-rated religiosity; religiosity-in-general did not seem to have a relation to interreligious prejudice. However, images of God correlated positively with anti-Islamic prejudice: This was true for the image of God as helper $(r=.14, p=.011)$ but stronger with the image of God as judge and redeemer $(r=.39, p<.001)$. Because the latter is associated with evangelical or Christian-fundamentalist beliefs, these results may indicate that evangelical and fundamentalist adolescents are especially inclined to agree with anti-Islamic statements. In contrast, the correlation of the image of God as judge and redeemer with anti-Semitic prejudice was lower $(r=.16, p<.002)$, which indicates that evangelical and fundamentalist religiosity of adolescents supports anti-Semitic prejudice to a considerably lower degree than anti-Islamic prejudice.

As to the correlations between the religious schemata and interreligious prejudice, the strongest correlations emerged for the schema ftr, which correlated strongly and negatively with anti-Islamic prejudice $(r=-.39, p<.001)$ and anti-Semitic prejudice $(r=-.47, p<$ $.001)$. The schema ttt correlated positively $(r=.34, p<.001)$ with anti-Islamic prejudice and lower with anti-Semitic prejudice $(r=.11, p<.036)$. This indicates that the literal, exclusivist, or absolutist truth claims about one's own religion have a positive relation with interreligious prejudice, in particular toward Islam. The lower association of ttt with anti-Semitic prejudice may be due to certain teachings, as we note in the Discussion. The third RSS schema, xenos, showed negative correlations with both anti-Islamic prejudice $(r=-.41, p<.001)$ and, much lower, with anti-Semitic prejudice $(r=-.16, p<.004)$. Taken together, all three RSS subscales, ttt, ftr, and xenos, had strong positive and negative correlations with anti-Islamic prejudice and, somewhat lower, with anti-Semitic prejudice. This indicates that the RSS is a strong predictor-the strongest we have in our data-for both interreligious prejudice variables.

\section{Religiosity, Images of God, and Religious Schemata as Predictors for Interreligious Prejudice: Results of Regression Analyses}

To assess the predictive effects of religiosity measures in relation to the RSS subscales for both variants of interreligious prejudice, we performed linear regression analyses and calculated two separate models for each dependent variable of interreligious prejudice: In Model 1, we entered, in a first step, the set of religiosity measures, religious self-identification, mystical experiences, and images of God, and in a second step the three RSS subscales. In a second model, the order of entry was reversed: In Step 1, we entered the three RSS subscales, in the second we entered the set of other religiosity measures. Of special interest are the $R^{2}$ changes between Model 1 and Model 2.

In the analysis with anti-Islamic prejudice as dependent variable (see Table 2), the difference in $R^{2}$ change ( $\Delta R^{2}=.15$ in Model $1 ; \Delta R^{2}=.05$ in Model 2) clearly indicated the superiority of the RSS subscales in accounting for the variance in anti-Islamic prejudice. With an adjusted $R^{2}$ of .29 , the RSS subscales alone display considerable predictability. Self-rated religiosity 
TABLE 2

Stepwise Regression Analyses of the Scales for Religiosity, Images of God, Mystical Experiences and Religious Schemata with anti-Islamic Prejudice as Dependent Variable

\begin{tabular}{|c|c|c|c|c|}
\hline & \multicolumn{2}{|c|}{ Model 1} & \multicolumn{2}{|c|}{ Model 2} \\
\hline & $\begin{array}{c}\text { Step } 1 \\
\beta(p)\end{array}$ & $\begin{array}{c}\text { Step } 2 \\
\beta(p)\end{array}$ & $\begin{array}{c}\text { Step } 1 \\
\beta(p)\end{array}$ & $\begin{array}{c}\text { Step } 2 \\
\beta(p)\end{array}$ \\
\hline Self-identification as "religious" & $-.22(.003)$ & $-.22(.001)$ & & $-.22(.001)$ \\
\hline God image: Judge \& redeemer & $.54(.000)$ & $.20(.016)$ & & $.20(.016)$ \\
\hline God image: Helper & $-.07(.415)$ & $-.07(.382)$ & & $-.07(.382)$ \\
\hline Mystical experiences & $.03(.534)$ & $.07(.196)$ & & $.07(.196)$ \\
\hline Truth of Texts \& Teachings & & $.26(.003)$ & $.24(.000)$ & $.26(.003)$ \\
\hline Fairness, Tolerance, \& Rational Choice & & $-.29(.000)$ & $-.30(.000)$ & $-.29(.000)$ \\
\hline Xenosophia/Interreligious Dialog & & $-.18(.001)$ & $-.23(.000)$ & $-.18(.001)$ \\
\hline$R^{2}$ (adjusted) & .19 & .33 & .29 & .33 \\
\hline$\Delta R^{2}$ & & .15 & & .05 \\
\hline
\end{tabular}

showed an inverse relationship with anti-Islamic prejudice $(\beta=-.22, p=.003)$-a pattern that did not emerge in the correlation matrix - and its regression weight did not decrease when the RSS subscales were entered. Also, the image of God as judge and redeemer emerged as the strongest predictor $(\beta=.54, p=.000)$ when entered with the set of religiosity measures without the RSS, but regression weight considerably decreased when the RSS subscales were entered.

As Table 3 demonstrates, the analyses with anti-Semitic prejudice as dependent variable indicate a lower overall power of religiosity measures to explain variance in anti-Semitic prejudice (adjusted $\left.R^{2}=.24\right)$. But again the difference in $R^{2}$ change $\left(\Delta R^{2}=.19\right.$ in Model 1 ; $\Delta R^{2}=.03$ in Model 2) indicates the stronger effect of the RSS subscales in accounting for

TABLE 3

Stepwise Regression Analyses of the Scales for Religiosity, Images of God, Mystical Experiences and Religious Schemata with Anti-Semitic Prejudice as Dependent Variable

\begin{tabular}{|c|c|c|c|c|}
\hline & \multicolumn{2}{|c|}{ Model 1} & \multicolumn{2}{|c|}{ Model 2} \\
\hline & $\begin{array}{c}\text { Step } 1 \\
\beta(p)\end{array}$ & $\begin{array}{r}\text { Step } 2 \\
\beta(p)\end{array}$ & $\begin{array}{c}\text { Step } 1 \\
\beta(p)\end{array}$ & $\begin{array}{c}\text { Step } 2 \\
\beta(p)\end{array}$ \\
\hline Self-identification as "religious" & $-.05(.506)$ & $-.05(.522)$ & & $-.05(.522)$ \\
\hline God image: Judge \& redeemer & $.37(.000)$ & $.18(.035)$ & & $.18(.035)$ \\
\hline God Image: Helper & $-.20(.027)$ & $-.20(.021)$ & & $-.20(.021)$ \\
\hline Mystical Experiences & $-.10(.091)$ & $-.07(.239)$ & & $-.07(.239)$ \\
\hline Truth of Texts \& Teachings & & $.17(.064)$ & $.09(.068)$ & $.17(.064)$ \\
\hline Fairness, Tolerance, \& Rational Choice & & $-.45(.000)$ & $-.47(.000)$ & $-.45(.000)$ \\
\hline Xenosophia/Interreligious Dialog & & $.08(.132)$ & $.03(.488)$ & $.08(.132)$ \\
\hline$R^{2}$ (adjusted) & .06 & .24 & .22 & .24 \\
\hline$\Delta R^{2}$ & & .19 & & .03 \\
\hline
\end{tabular}


the variance in anti-Semitic prejudice. Explanatory power is indicated for ftr only, the other two RSS subscales, $t t t$ and xenos do not reach significance. ${ }^{4}$ Thus we conclude that for $t \mathrm{tt}$ and xenos no significant effects on anti-Semitic prejudice are indicated, whereas ftr emerges as strongest predictor.

\section{Analysis of Variance of Interreligious Prejudice Variables for Three Religious Schema Groups}

For further analysis, three different groups were constructed on the basis of high agreement (fourth quartile on the respective subscale) on the three RSS subscales: Group A $(n=43)$ had high agreement with ttt, Group B $(n=53)$ had high agreement with ftr, and Group C $(n=64)$ had high agreement with xenos. With these groups included in an independent variable, an analysis of variance was performed with the $z$ scores of anti-Islamic prejudice, antiSemitic prejudice, and a compilation of both in a new variable called interreligious prejudice as dependent variables. Analyses indicate that the dependent variables were significantly affected: Anti-Islamic prejudice, $F(2,157)=26.481, p<.001$; anti-Semitic prejudice, $F(2,157)=$ $3.234, p<.008$; the interreligious prejudice, $F(2,157)=18.896, p<.001$. Z-score mean differences are presented in Figure 1.

Post hoc tests (Scheffé's procedure) indicated that, for anti-Islamic prejudice and interreligious prejudice, the differences between Group A (high agreement on ttt) and Group B (high agreement on ftr), and between Group A (high agreement on ttt) and Group C (high agreement on xenos), were significant at the $p<.001$ level. For anti-Semitic prejudice, only the difference between Group A (high on ttt) and Group C (high on xenos) was significant $(p=.009)$. All differences between Groups B (high on ftr) and C (high on xenos) were nonsignificant. Thus, with moderate or high agreement to the prejudice variables, Group A (high agreement on ttt) indicates a significant and strong contrast especially to Group C (high agreement with xenos).

Going in more detail, for anti-Islamic prejudice, analyses reveal the greatest mean difference of 1.35 ( $p \leq .001$ ) between Group A (high on $\mathrm{ttt}$ ) and Group C (high on xenos). The mean difference in anti-Islamic prejudice between Group A (high on ttt) and Group B (high on $\mathrm{ftr})$ is with $1.22(p<.001)$ only slightly lower. For anti-Semitic prejudice, a significant mean difference exists only between Group A (high on ttt) and C (high on xenos), and this difference is with .49 ( $p=.009)$ relatively small. For the combined variable, interreligious prejudice, mean differences are again high: Between Groups A (high on ttt) and C (high on xenos), interreligious prejudice drops by $1.16(p<.001)$, and between Groups A (high on ttt) and B (high on ftr) by $1.00(p<.001)$. Taken together, mean differences reveal a clear pattern.

\section{DISCUSSION}

The results of our analyses showed that religiosity has a considerable effect on interreligious prejudice. But differences between styles of religiousness call for attention. For example, for

\footnotetext{
${ }^{4}$ The nonsignificance of $\mathrm{ttt}$ and $\mathrm{ftr}$ is not explained by collinearity ( $V I P<1.3$ for all variables); nevertheless, when $\mathrm{ftr}$ is excluded from the regression, xenos has a small but significant regression weight $(\beta=-.14, p=.018)$, whereas $\mathrm{ttt}$ remains insignificant.
} 


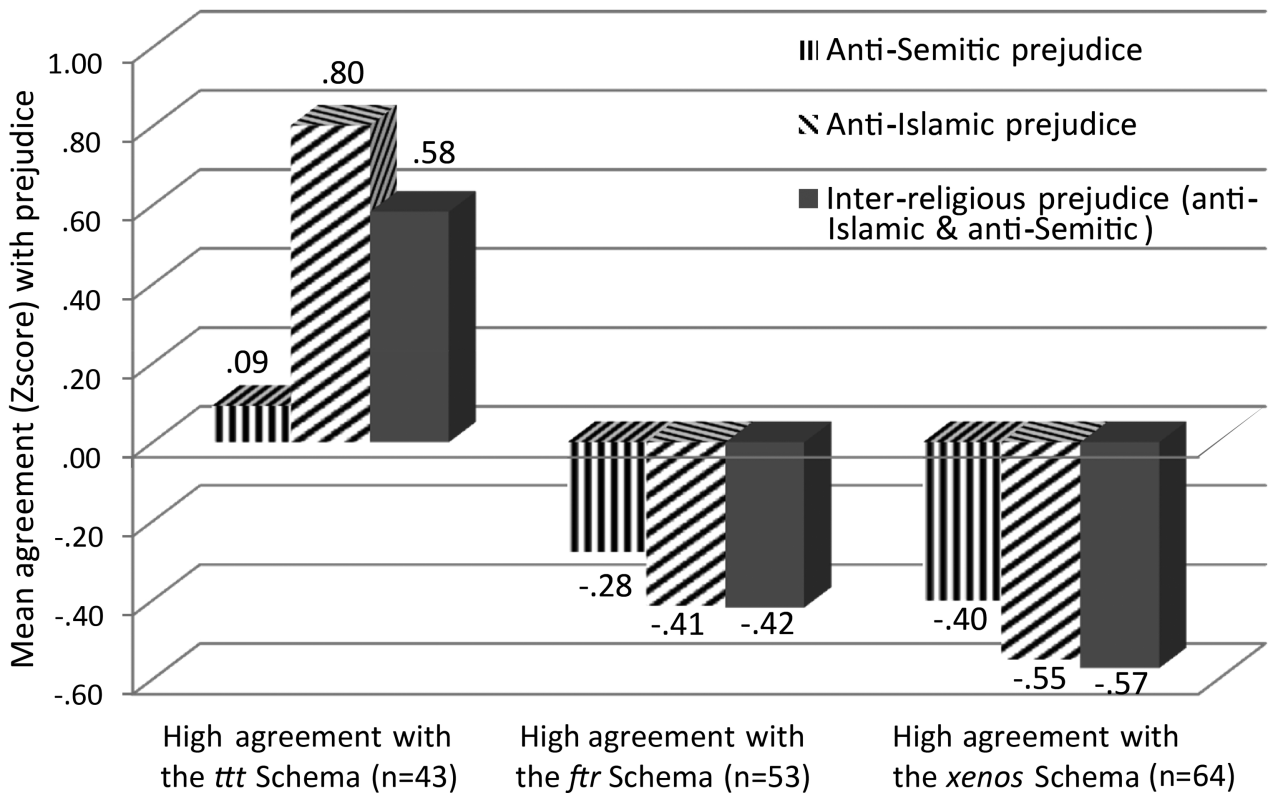

FIGURE 1 Interreligious prejudice in groups constructed on the basis of agreement to RSS subscales.

self-rated religiosity, our results indicate an almost zero correlation with anti-Islamic prejudice and a considerable negative regression weight on anti-Islamic prejudice. These results do not confirm accounts of a positive association between religiousness and interreligious prejudice such as the moderate but significant association reported by Küpper and Zick (2010; Zick, Küpper, \& Hövermann, 2011). Instead, our results suggest another explanation that is consistent with but also qualify Küpper and Zick's results. It is specific images of God, in particular the image of God as judge and redeemer, that promotes prejudice toward Muslims and Jews. Moreover, it is a specific religious style that is associated with the schema ttt, which predicts anti-Islamic prejudice. These results confirm, for the German adolescents in this study, the effects of the ethnocentric type of religion (Allport, 1954/1979) for generating interreligious prejudice.

Our data indicate a weaker promoting effect of an absolutistic and fundamentalist type of religion on anti-Semitic prejudice. This lower effect for anti-Semitic prejudice reflects Baum's (2009) findings. An explanation could be the counterweight of pro-Semitic beliefs among the vast majority of our Christian respondents, because even fundamentalist teachings do not include anti-Semitic content but rather strongly proclaim to honor the Jewish origin of Christianity.

Two of the religious schemata, xenos and ftr, showed the strongest inverse relationships with interreligious prejudice. There were differences between them, however. Both ftr and xenos emerged as strong negative predictors of anti-Islamic prejudice but only ftr showed this effect for anti-Semitic prejudice. This finding suggests reconsidering the relation between 
religiosity and prejudice-beyond the simple formulae "religiosity $=$ prevention of prejudice" and "religion = promotion of prejudice." There is both a promoting effect of the absolutistic, exclusivist, and literal understanding of one's own religion, which is assessed by the ttt subscale and which reflects Allport's (1954/1979) "religion of an ethnocentric order," and there is the preventive effect of specific religious styles that promote tolerance and readiness for dialog and learning in the encounter with the alien, which reflect Allport's (1954/1979) "religion of a universalistic order."

To state this more fully: We claim to take up the tradition of Allport's conceptualization and operationalization of religiosity in regard to prejudice but conceptualize and operationalize religiosity in a different way, namely, in terms of religious styles and schemata, which in turn are derived from Fowler's model of faith development. And with the assessment of religiosity using the Religious Schema Scale, our research reveals an association of certain schemata of religion (subscale $\mathrm{ttt}$ ) with higher prejudice, and of other religious schemata (subscales ftr and xenos) with lower prejudice. We regard this as a step forward, because a model of religious styles and schemata-with a perspective on religious development-may advance and deepen the psychological understanding of the relation of religion and prejudice. (And, vice versa, this is a successful step in reformulating Fowler's faith development project in the terms of psychological theory and research.)

That the assessment of religious schemata might open a perspective on religious development can be argued with respect to the analysis of variance findings that were presented in Figure 1: Group A with high scores on ttt can be expected to prefer a mythic-literal (Fowler's, 1981, Stage 2) or instrumental-reciprocal religious style (Streib, 2001), Group B with high scores on ftr can be expected to prefer the individuative-systemic religious style (which corresponds to Fowler's, 1981, Stage 4), and Group C with high scores on xenos can be expected to prefer the conjunctive (Fowler's, 1981, Stage 5) or dialogical religious style (Streib, 2001). Based on assumptions from the philosophy of religion, the model of religious styles (Streib, 2001), not much different from Fowler's (1981) model of faith development, claims a developmental hierarchy: Xenosophic and dialogical attitudes toward (the religion of) the other are regarded more advanced and developmentally higher than the retreat to absolutistic truth claims that is not open for alternative interpretations. Thus, if it is adequate to understand such differences in terms of a developmental hierarchy, Figure 1 indicates that anti-Islamic and anti-Semitic prejudice decline with progressing religious development. Insofar our results parallel the findings of James et al. (2011) and of Leak and Finken (2011), but the RSS using three schemata allows for a more detailed account of religious development. Finally, results of our study indicate that, compared to other measures of religiosity, the RSS has greater power as predictor for both promotion and prevention of interreligious prejudice.

Our study certainly has limitations. The sample size is not representative to the adolescent population in Germany, better educated and religiously affiliated subjects are overrepresented; thus, our results may not adequately portrait lower educated and religiously unaffiliated adolescents. Given the small number of Islamic adolescents in our original sample that needed to be excluded from the analyses, our data unfortunately did not allow for any comparison of Christian/autochthonous and Muslim/allochthonous adolescents. Future research might include a larger sample of Muslim adolescents. Also from the results of our study, we cannot easily draw conclusion for the adult population. Finally, the instruments that we used for the assessment of interreligious prejudice are direct measures and thus vulnerable to the effects of social 
desirability in these sensitive research domains; a supplementation by indirect measures is recommended for future research.

However, one conclusion we may draw from our research: Although everyone in the psychology of religion should agree with Allport (1954/1979) that "we cannot speak sensibly of the relation between religion and prejudice without specifying the sort of religion we mean and the role it plays in the personal life" (p. 456), it may be time to differentiate further and attend to religious styles and schemata: Religious experiences and beliefs, but also specific structural cognitive schemata of religion, may promote interreligious prejudice, whereas other schemata may prevent hostility and promote xenophilia and xenosophia.

\section{REFERENCES}

Allport, G. W. (1979). The nature of prejudice. Cambridge, MA: Perseus. (Original work published 1954)

Allport, G. W. (1966). The religious context of prejudice. Journal for the Scientific Study of Religion, 5, 447-457.

Allport, G. W., \& Ross, J. M. (1967). Personal religious orientation and prejudice. Journal of Personality and Social Psychology, 5, 432-443.

Altemeyer, B. (2003). Why do religious fundamentalists tend to be prejudiced? The International Journal for the Psychology of Religion, 13, 17-28. doi:10.1207/S15327582IJPR1301_03

Altemeyer, B., \& Hunsberger, B. (1992). Authoritarianism, religious fundamentalism, quest and prejudice. The International Journal for the Psychology of Religion, 2, 113-133. doi:10.1207/s15327582ijpr0202_5

Altemeyer, B., \& Hunsberger, B. (2004). A revised religious fundamentalism scale: The short and sweet of it. The International Journal for the Psychology of Religion, 14, 47-54.

Altemeyer, B., \& Hunsberger, B. (2005). Fundamentalism and authoritarianism. In R. F. Paloutzian \& C. L. Park (Eds.), Handbook of the psychology of religion and spirituality (pp. 378-393). New York, NY: Guilford.

Batson, C. D., Schoenrade, P., \& Ventis, W. L. (1993). Religion and the individual: A social-psychological perspective. New York, NY: Oxford University Press.

Baum, S. K. (2009). Christian and Muslim anti-Semitic beliefs. Journal of Contemporary Religion, 24, 137-156.

Donahue, M. J. (1985). Intrinsic and extrinsic religiousness: Review and meta-analysis. Journal of Personality and Social Psychology, 48, 400-419.

Fowler, J. W. (1981). Stages of faith. The psychology of human development and the quest for meaning. San Francisco, CA: Harper \& Row.

Girard, R. (1987). Das Heilige und die Gewalt [The holy and the violence]. Zürich, Switzerland: Benziger.

Girard, R. (1998). Der Sündenbock [The scapegoat]. Zürich, Switzerland: Benziger.

Hall, D. L., Matz, D. C., \& Wood, W. (2010). Why don't we practice what we preach? Social-cognitive motives behind religious racism. Personality and Social Psychology Bulletin, 14, 126-139.

Heitmeyer, W. (2002). Gruppenbezogene Menschenfeindlichkeit. Die theoretische Konzeption und erste empirische Ergebnisse [Group-focussed enmity. Theoretical conception and first empirical results]. In W. Heitmeyer (Ed.), Deutsche Zustände, Folge 1 (pp. 15-34). Frankfurt, Germany: suhrkamp.

Heitmeyer, W. (2007). Gruppenbezogene Menschenfeindlichkeit. Ein normaler Dauerzustand? [Group-focussed enmity. A normal permanent state of affairs]. In W. Heitmeyer (Ed.), Deutsche Zustände, Folge 5 (pp. 15-36). Frankfurt, Germany: suhrkamp.

Heitmeyer, W. (Ed.). (2011). Deutsche Zustände, Folge 10 [German state of affairs]. Frankfurt, Germany: suhrkamp.

Hood, R. W., Hill, P. C., \& Spilka, B. (2009). The psychology of religion: An empirical approach (4th ed.). New York, NY: Guilford.

Hunsberger, B., \& Jackson, L. M. (2005). Religion, meaning, and prejudice. Journal of Social Issues, 61, 807-826. doi:10.1111/j.1540-4560.2005.00433.x

Hunsberger, B., Owusu, V., \& Duck, R. (1999). Religion and prejudice in Ghana and Canada: Religious fundamentalism, right-wing authoritarianism and attitudes toward homosexuals and women. The International Journal for the Psychology of Religion, 9, 181-194. 
James, W., Griffiths, B., \& Pedersen, A. (2011). The "making and unmaking” of prejudice against Australian Muslims and gay men and lesbians: The role of religious development and fundamentalism. The International Journal for the Psychology of Religion, 21, 212-227.

Küpper, B. (2010). Zum Zusammenhang von Religiosität und Vorurteilen: Eine empirische Analyse [On the relation of religiosity and prejudice: An empirical analysis]. Ethik und Gesellschaft, 2/2010: Der ganz alltägliche Rassismus. Retrieved from http://www.ethik-und-gesellschaft.de/mm/EuG-2-2010_Kuepper.pdf

Küpper, B., \& Zick, A. (2005). Riskanter Glaube: Religiosität und Abwertung [Risky faith: Religiosity and devaluation]. In W. Heitmeyer (Ed.), Deutsche Zustände, Folge 4 (pp. 179-190). Frankfurt, Germany: suhrkamp.

Küpper, B., \& Zick, A. (2010). Religion and prejudice in Europe. New empirical findings-NEF initiative on religion and democracy in Europe. London, UK: Alliance Publishing Trust. Retrieved from http://www.nefic.org/content/ publications

Leak, G. K. (2008). Factorial validity of the Faith Development Scale. The International Journal for the Psychology of Religion, 18, 123-131.

Leak, G. K., \& Finken, L. L. (2011). The relationship between the constructs of religiousness and prejudice: A structural equation model analysis. The International Journal for the Psychology of Religion, 21, 43-62.

Leak, G. K., Loucks, A. A., \& Bowlin, P. (1999). Development and initial validation of an objective measure of faith development. The International Journal for the Psychology of Religion, 9, 105-124.

Nakamura, Y. (2000). Xenosophie: Bausteine für eine Theorie der Fremdheit [Xenosophia: Building blocks for a theory of alienness]. Darmstadt, Germany: Wissenschaftliche Buchgesellschaft.

Rowatt, W. C., \& Franklin, L. M. (2004). Christian Orthodoxy, Religious Fundamentalism, and Right-Wing Authoritarianism as Predictors of Implicit Racial Prejudice. The International Journal for the Psychology of Religion, 14, 125-138. doi:10.1207/s15327582ijpr1402_4

Streib, H. (2001). Faith development theory revisited: The religious styles perspective. The International Journal for the Psychology of Religion, 11, 143-158.

Streib, H. (2008). Gewalt [Violence]. In L. Charbonnier \& D. Korsch (Eds.), Der verborgene Sinn. Religiöse Dimensionen des Alltags (pp. 179-184). Göttingen, Germany: Vandenhoeck \& Rupprecht.

Streib, H., \& Gennerich, C. (2011). Jugend und Religion. Bestandsaufnahmen, Analysen und Fallstudien zur Religiosität Jugendlicher [Youth and religion. Stocktaking, analyses and case studies on the religiosity of adolescents]. Weinheim, Germany: Juventa Verlag.

Streib, H., Hood, R. W., Keller, B., Csöff, R.-M., \& Silver, C. (2009). Deconversion. qualitative and quantitative results from cross-cultural research in Germany and the United States of America. Research in Contemporary Religion, 5. Göttingen, Germany: Vandenhoeck \& Ruprecht.

Streib, H., Hood, R. W., \& Klein, C. (2010). The Religious Schema Scale: Construction and initial validation of a quantitative measure for religious styles. The International Journal for the Psychology of Religion, 20, 151-172. doi:10.1080/10508619.2010.481223

Waldenfels, B. (1990). Der Stachel des Fremden [The goad of the alien]. Frankfurt, Germany: Suhrkamp.

Waldenfels, B. (1997). Topographie des Fremden [Topography of the alien]. Frankfurt, Germany: Suhrkamp.

Zick, A., Küpper, B., \& Hövermann, A. (2011). Intolerance, prejudice and discrimination. A European report. Berlin, Germany: Friedrich-Ebert-Stiftung. Retrieved from http://www.uni-bielefeld.de/ikg/zick/ZicketalGFEengl.pdf 
This article was downloaded by: [Universitaetsbibliothek Bielefeld], [Professor Heinz Streib]

On: 10 September 2014, At: 03:05

Publisher: Routledge

Informa Ltd Registered in England and Wales Registered Number: 1072954 Registered office: Mortimer House, 37-41 Mortimer Street, London W1T 3J H, UK

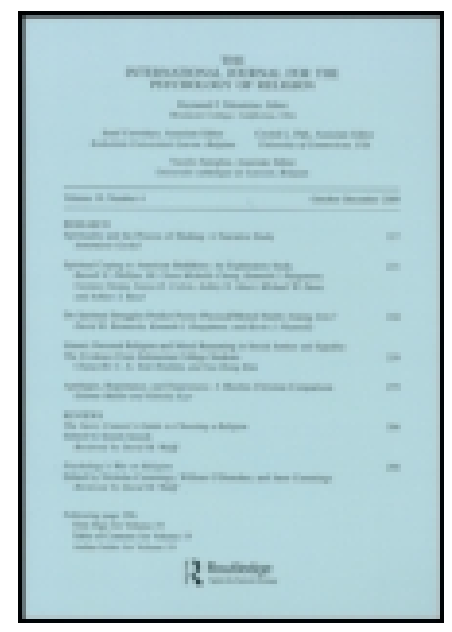

\title{
The International J ournal for the Psychology of Religion
}

Publication details, including instructions for authors and subscription information:

http:// www. tandfonline.com/loi/ hjpr20

\section{Religious Styles Predict Interreligious Prejudice: A Study of German Adolescents with the Religious Schema Scale}

\author{
Heinz Streib ${ }^{a} \&$ Constantin Klein ${ }^{a}$ \\ ${ }^{a}$ Research Center for Biographical Studies in Contemporary Religion, \\ Bielefeld University, Germany \\ Accepted author version posted online: 09 J un 2013. Published \\ online: 13 J an 2014.
}

To cite this article: Heinz Streib \& Constantin Klein (2014) Religious Styles Predict Interreligious Prejudice: A Study of German Adolescents with the Religious Schema Scale, The International J ournal for the Psychology of Religion, 24:2, 151-163, DOI: 10.1080/10508619.2013.808869

To link to this article: http:// dx.doi.org/ 10.1080/ 10508619.2013.808869

\section{PLEASE SCROLL DOWN FOR ARTICLE}

Taylor \& Francis makes every effort to ensure the accuracy of all the information (the "Content") contained in the publications on our platform. However, Taylor \& Francis, our agents, and our licensors make no representations or warranties whatsoever as to the accuracy, completeness, or suitability for any purpose of the Content. Any opinions and views expressed in this publication are the opinions and views of the authors, and are not the views of or endorsed by Taylor \& Francis. The accuracy of the Content should not be relied upon and should be independently verified with primary sources of information. Taylor and Francis shall not be liable for any losses, actions, claims, proceedings, demands, costs, expenses, damages, and other liabilities whatsoever or howsoever caused arising directly or indirectly in connection with, in relation to or arising out of the use of the Content.

This article may be used for research, teaching, and private study purposes. Any substantial or systematic reproduction, redistribution, reselling, loan, sub-licensing, systematic supply, or distribution in any form to anyone is expressly forbidden. Terms \& 
Conditions of access and use can be found at http://www.tandfonline.com/page/termsand-conditions 